\title{
Two contrasted future scenarios for the French agro-food system
}

\author{
Gilles Billen *, Julia Le Noë, Josette Garnier \\ Sorbonne Université-CNRS-EPHE, UMR 7619 Metis, BP123, Tour 56-55, 4 Place Jussieu, 75005 Paris, France
}

\section{H I G H L I G H T S}

- Two prospective scenarios for French agriculture at the 2040 horizon are described.

- $\mathrm{O} / \mathrm{S}$ pursues the current trends of agriculture opening and specialization.

- A/R/D considers autonomy of farming systems, reconnection and a demitarian diet.

- The storylines are translated into a quantitative nutrient fluxes description.

- The A/R/D scenario can feed France with better environmental performances.
Keywords:

Agro-food system

Prospective scenarios

Agricultural specialization

Organic farming

Demitarian diet

GRAFS
G R A P H I C A L A B S T R A C T

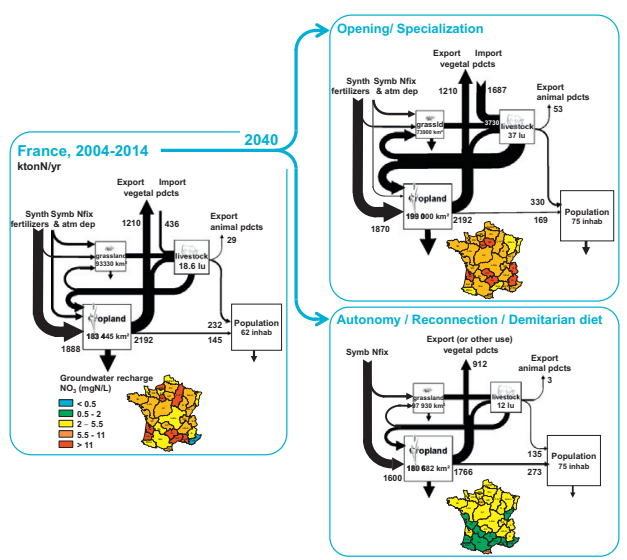

\section{A B S T R A C T}

Narratives of two prospective scenarios for the future of French agriculture were elaborated by pushing several trends already acting on the dynamics of the current system to their logical end. The first one pursues the opening and specialization characterizing the long-term evolution of the last 50 years of most French agricultural regions, while the second assumes a shift, already perceptible through weak signals, towards more autonomy at the farm and regional scales, a reconnection of crop and livestock farming and a more frugal human diet. A procedure is proposed to translate these qualitative narratives into a quantitative description of the corresponding nutrient fluxes using the GRAFS (Generalized Representation of Agro-Food Systems) methodology, thus allowing a comprehensive exploration of the agronomical and environmental performance of these two scenarios. The results show that the pursuit of the opening and specialization of French agriculture, even complying with regulations regarding reasoned fertilization, would result in considerable environmental burdens namely in terms of water pollution. The scenario generalizing organic farming practices, reconnection of crop and livestock farming systems and a demitarian human diet makes it possible to meet the future national food demand while still exporting significant amounts of cereals to the international market and ensuring better groundwater quality in most French regions.

\footnotetext{
* Corresponding author.

E-mail address: gilles.billen@upmc.fr (G. Billen).
}

\section{Introduction}

Being at the junction of several of the UN Sustainable Development Goals (UN, 2015), agriculture and human nutrition systems play a major role in human subsistence and welfare but are also strongly 
involved in the exceedance of safe planetary thresholds regarding $\mathrm{N}$ and P cycle perturbations, biodiversity loss and climate change (Rockström et al., 2009; de Vries et al., 2013).

In a short review paper, Smith (2013) showed that the challenge of feeding the future world population while reducing adverse environmental effects of agriculture will only be possible by combining sustainable intensification of cropping systems with fundamental systemic changes in food supply and demand, including changes in diet, reduction of waste and redesign of production systems.

During the last decade several prospective studies have been published exploring scenarios of a possible future for agro-food systems at the global scale. Among them Billen et al. (2015) and Erb et al. (2016) both explored the range of possibilities of feeding the projected 2050 world population by varying agricultural intensification, livestock feed composition and human diet, and demonstrated that a vast range of options exists for feeding the world, without expanding the global agricultural area. As also underlined by Kastner et al. (2012), the human diet (more specifically the fraction of livestock products in total protein ingestion) appeared as the strongest determinant of the "option space."

Lassaletta et al. (2016) and Muller et al. (2017) further showed that organic agriculture, if combined with structural measures including reduction of food wastage and animal product consumption would make it possible to meet the requirements of the current world population with much less pollution, and less long-distance trade, hence a higher degree of food sovereignty. Using the economic and biophysical model MagPIE, Schmitz et al. (2012) concluded that extension of food trade liberalization would increase trade fluxes, reduce global agriculture production costs, but substantially increase environmental damage and GHG emissions compared with a scenario with the current level of trade tariff. The role of trade was also addressed by Kastner et al. (2014), who concluded that the potential to reduce land demand by closing yield gaps with available production techniques is substantially larger than the hypothetical land savings achieved through international trade. The former strategy would also help poor importing regions to increase their self-sufficiency in terms of crop products, making them less vulnerable to global market fluctuations. By comparing the requirements and local production of food and feed at different scales to assess the current food self-sufficiency of populations, Pradhan et al. (2014) found that in 2000 about one billion people from Asia and Africa require cross-continental agricultural trade. By 2050, according to different scenarios regarding the population increase, diet composition and agronomical techniques, the number of people depending on international trade would vary between 1.5 and 6 billion. Further, climate change might increase the need for international agricultural trade by 4-16\% (Pradhan et al., 2014).

As seen from this rapid and non-exhaustive overview of the prospective work carried out at the global scale, human diet, cropping techniques (in particular organic versus chemical farming), livestock feeding mode and the role of international trade are four major issues when addressing the challenge of future agro-food systems. These four issues are not independent of each other and two types of contrasted scenarios can be distinguished: those describing a future world with increased long-distance trade exchanges, further specialization and industrialization of agricultural systems, with a wide range of human diet according to economic development, and others privileging local reconnection of food production and consumption, of crop and livestock systems, as well as a more equitable diet.

To give further substance to the debates between these two opposite views of the future global agro-food system, it might be meaningful to apply them at a smaller scale, in order to consider them in view of the practical reality of regional situations. France is an interesting case study regarding industrialized countries, because it is, on the whole, the world's eighth largest producer and fourth largest agricultural exporter (www.fao.org/faostat), but displays a wide range of contrasting regional situations. Indeed, the French agro-food system is presently characterized by a high level of specialization, with territories devoted to intensive crop farming, disconnected from livestock husbandry, and others with very high livestock densities that are highly dependent on feed imports from remote regions, while large areas remain as a form of mixed crop and livestock farming (Le Noë et al., 2017). Examining the long-term trajectory of French regional agro-food systems showed that the current state of affairs has been established during the second half of the 20th century, under the impulse of a voluntarist public policy, from a previous long-lasting situation where connected crop and livestock farming systems dominated everywhere (Le Noë et al., 2018a). This public policy voluntarism diminished considerably after the 1980 's, giving way to more liberal governance that reinforced openness and specialization, while environmental measures tended to limit, more or less successfully, the pollution generated (Bureau and Thoyer, 2014).

Here we describe two possible futures for the French agro-food system by exploring the ultimate outcome of a number of opposite trends co-existing in the current situation, leading to two contrasted sets of storylines, each qualitatively describing what the French agro-food system could be at the horizon of 3-4 decades (Section 2). We then use the GRAFS methodology to translate these storylines into a coherent and quantitative description of $\mathrm{N}$ and $\mathrm{P}$ fluxes throughout the system at the regional scale. The GRAFS approach was first developed by Billen et al. (2014) as an accounting method for providing a picture of $\mathrm{N}$ fluxes at the global scale, making it possible to check the coherence of estimates coming from various independent sources, based on the criterion of mass conservation. It was later applied to the scale of 33 regions in France and extended to P and C fluxes by Le Noë et al. (2017). In the present paper (Section 3), we thus further enrich the GRAFS methodology in order to use it as a tool for scenario elaboration, regarding demography and human diet, cropping systems and connection to livestock systems. Finally (Section 4), the detailed descriptions of the two scenarios obtained are used to explore their agronomic performances, their capacity to meet the food requirements of the French population and their position in international exchanges, as well as their environmental imprint in terms of nutrient cycling and resource requirements.

\section{The storylines of the scenarios}

Two contrasted scenarios of the future French agro-food system were elaborated, not to predict the future or to prescribe what it or should not be. The aim is instead to discern within the present dynamics of the system, a number of trends, currently contradicting each other, and to explore the trajectory that could be followed if these trends were pushed to their extreme. The following storylines therefore mix facts about certain trends that can be perceived in the current French agro-food system and fictions about how they may evolve at the 2040-2050 horizon.

\subsection{Pursuit of past trend towards opening and specialization: the $\mathrm{O} / \mathrm{S}$ scenario}

The most striking trend in the development of French agriculture over the last 50 years is its voluntarist integration into international markets. Export of French cereals has regularly increased since the 1960 's, while import of feed, mainly soybean from South America, has increased fivefold (Fig. 1a, b). This has gone hand in hand with the specialization, in stockless crop farming of the most fertile lowland regions, such as the Paris and Aquitaine Basins and the Alsace Plain, while the Great West regions specialized in intensive livestock farming (Le Noë et al., 2017, 2018b). Large harbor and land transport infrastructures have been established and are still projected, extending the harbor hinterland to remote grain-producing areas (Duszinski, 2013; Haropa, 2014). Support for this globalization of French agriculture was recurrently re-affirmed in political declarations at the national level, as illustrated by the declaration of former French president Sarkozy, 2009 “We need to rebuild a policy and maritime ambition for France, around 

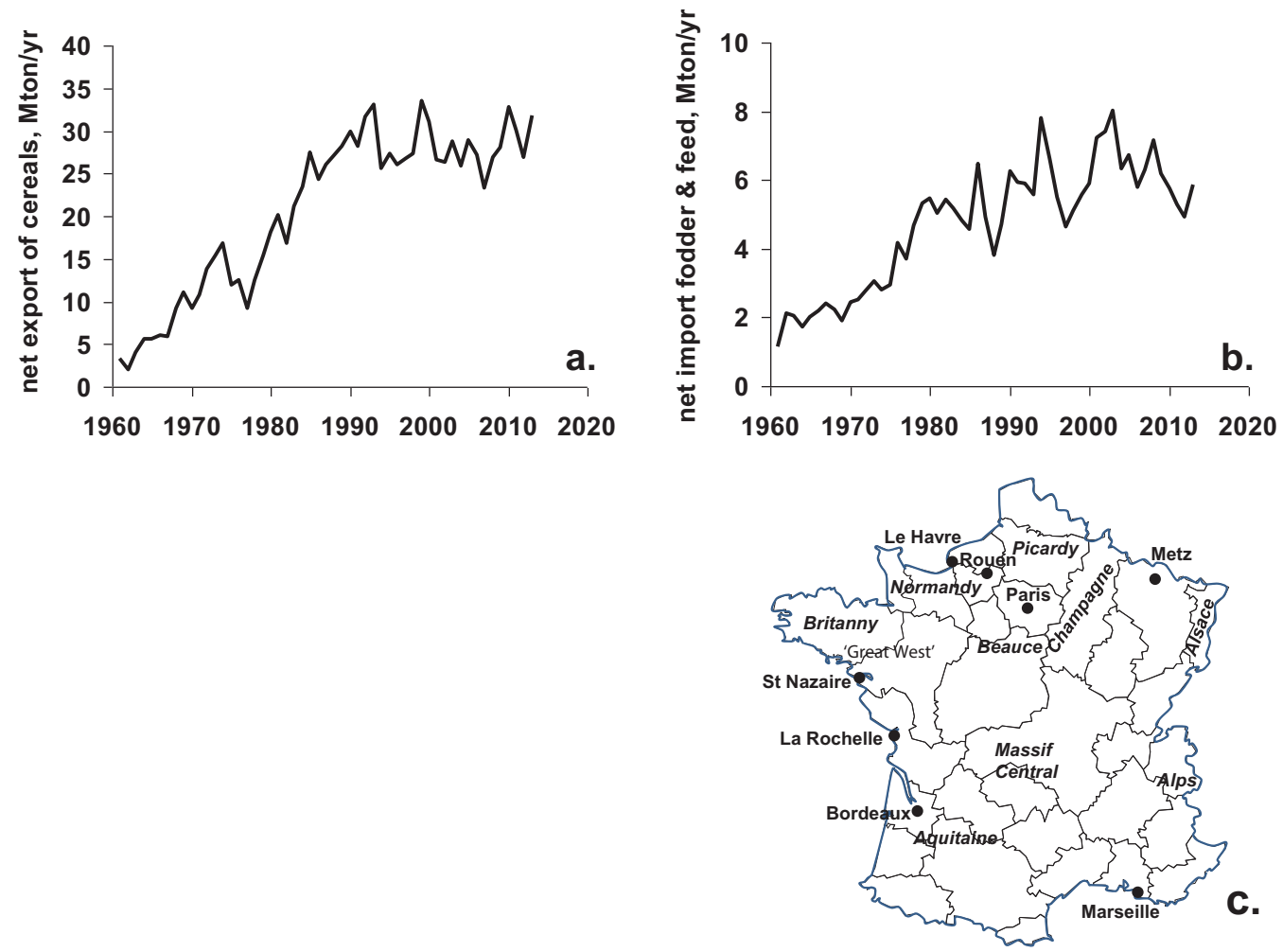

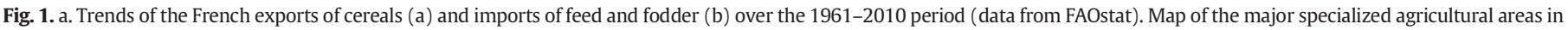
France and the main harbor infrastructures for the trade of agricultural commodities (c).

emerging issues (...) of a globalized world that breathes through international trade" and his successor F. Hollande in 2012: "Our agriculture has a major role to play in the supply of agricultural commodities and in the balance of world markets. (...) France must help feed the population of the planet." This view of French agricultural development driven by exportation was shared by the majority farmers' union (FNSEA) as well as by the largest farming cooperatives, many of which have maintained international positions in some key food sectors (Tereos Group for sugar, Avril Group for oils, etc.). Agrofuels and green chemistry also offer similar development perspectives (Ministère de l'Agriculture, 2012). In the O/S scenario, these trends of opening and specialization of cropping systems are assumed to intensify. Regarding animal production, the milk sector is opening to international trade mostly through the mass production and export of milk powder, the demand for which continues to rise as it has over the last five decades (Bureau and Thoyer, 2014). The economic profitability of this industrialized production requires large farms concentrating thousands of animals, fed in the barn with imported feed.

Strong environmental regulations have been enacted, however, to limit the pollution generated by these agricultural activities. In areas defined as vulnerable to nitrate contamination, farmers were constrained to limit the soil $\mathrm{N}$ balance below a value of $50 \mathrm{~kg} \mathrm{~N} / \mathrm{ha} / \mathrm{yr}$, and to strictly optimize nitrogen and phosphorus fertilization by following provisional calculations formulas established by COMIFER (www.comifer.asso.fr/). On the other hand, the maximum allowed animal density was limited by the capacity of crop or grassland areas to absorb the effluents produced and managed (typically $170 \mathrm{~kg} \mathrm{~N} / \mathrm{ha} / \mathrm{yr}$ ), unless a treatment unit would be is installed. Although these regulations were often felt too restrictive by farmers, we have considered they will still be observed in the future.

Regarding the local food demand in France, no significant change occurred in the average diet, but the share of animal products in total protein consumption continued to be linked to economic indicators such as revenue at the individual scale (Le Nechet et al., 2006) or GDP at the national scale (Billen et al., 2013), and keeped increasing. The great distribution sector increased its capacity to capture most of the added value of the domestic food supply chain, maintaining low prices to farmers and promoting processed food rather than raw products.

\subsection{Changing towards autonomy, reconnection and a demitarian diet: the $A / R / D$ scenario}

Following repeated crises and scandals in the food sector such as the mad cow crisis from 1986 to 2004, the chicken contamination with dioxin in 1999, the discovery of horse meat in pure beef lasagna in 2013, the Fipronil egg scandal in 2017, of bacteriological contamination of milk powder in 2018 (Le Monde, 2017), a strong consumer and citizen movement has developed, aiming at taking control of the food supply. Multiple initiatives have flourished such as community-supported agriculture, shared gardens and in general, an increased demand for products from organic agriculture, guaranteeing the absence of pesticide residues (Fig. 2). While these trends were still minor in the early 2000 's, in this A/R/D scenario, these movements are assumed to increase rapidly in terms of audience and the scope of their claims, from mainly health-based issues in the beginning, evolving into radical social movements, up to the point of constituting a real driver of change in the agro-food sector.

Together with growing concerns regarding health issues related to pesticides, the instability of market prices of fertilizers and agricultural products (Mew, 2016; Timmer, 2008) was a strong incentive to switch to organic practices. This movement was encouraged by the authorities in charge of the protection of water resources, concerned by the increasing number of drinking water wells closed because of agricultural contamination (440 wells closed between 1998 and 2008; Direction Générale de la Santé, 2012).

Long and diversified organic rotations, with a large proportion of forage legumes, allowed farmers to wean off their dependence on synthetic fertilizers and pesticides (Crowder et al., 2010). Furthermore, 

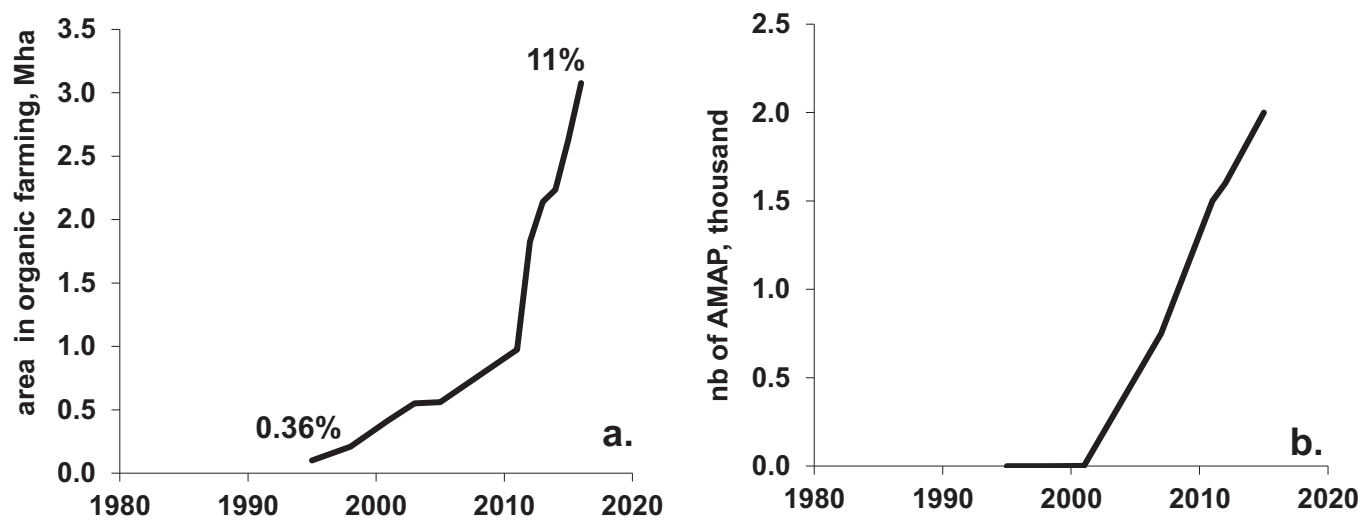

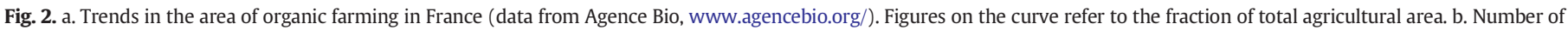
community-supported agriculture (AMAP) contracts in France (data from www.miramap.org/).

local coupling with animal farming provided the best output for forage production, as in the examples described by Garnier et al. (2016) and Anglade et al. (2017). In this way, the specialized cropping regions evolved towards more diversified mixed crop and livestock farming patterns. The Afterres2050 scenario (Couturier et al., 2017), elaborated by an environmentalist NGO and officially supported by several local authorities, has been very influential in this direction.

At the same time, a lively ethical debate opposed the antispecist movement (with their activist associations such as "L214 ethique et animaux" (https://www.1214.com/) preaching a vegan diet (Singer, 1975) and the defenders of carnivorism (Lestel, 2017), with the intermediate position of those considering the long-term relationships between humans and animals as a constituent element of our society (Porcher, 2011). This debate had at least the merit of putting in the spotlight the horrible practices of industrial animal production so that the demand shifted away from mass production to higher-quality food issued from more extensive livestock systems. At the same time, we assumed that animal protein in the diet was gradually reduced to half its current value, in accordance with the recommendations of environmentalists (http://www.nine-esf.org/node/281/index.html) as well as nutritionists (Maillot et al., 2011). As a whole, the number of livestock decreased considerably at the national scale but was much more evenly distributed among the different regions, so that it could rely on grass and local forage production instead of imported feedstuff.

\section{Translation of the storylines into a coherent GRAFS description}

The above storylines provide two contrasting qualitative pictures of possible future French agro-food systems. The GRAFS approach, a biogeochemical accounting method describing N, P and C fluxes between cropland, grassland, livestock and human nutrition (Le Noë et al., 2017), makes it possible to translate them into quantitative descriptions to test their coherence and assess their environmental imprint. It requires, however, a number of quantitative hypotheses, which are briefly discussed below and described in greater detail in the Supplementary material SM1 and its appended spreadsheets.

\subsection{Demography}

Population projections at the 2040 horizon are provided by INSEE (www.insee.fr/fr/statistiques/2529884) (Fig. 3b). We used their high estimate for the $\mathrm{O} / \mathrm{S}$ scenario. The INSEE projection indicates a population increase in the west and south of France, while the demographic rate of growth in the north and northeastern regions would be much

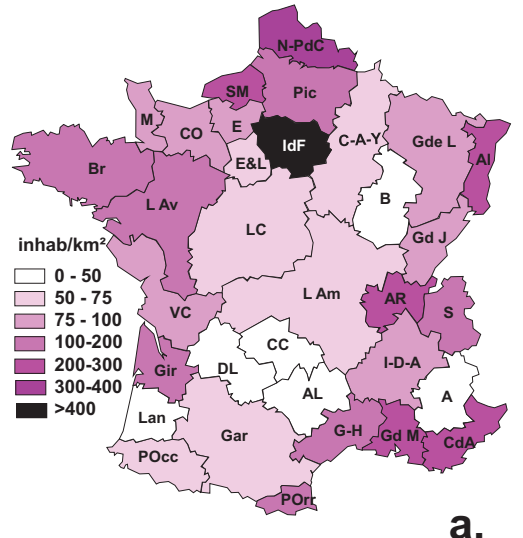

a.

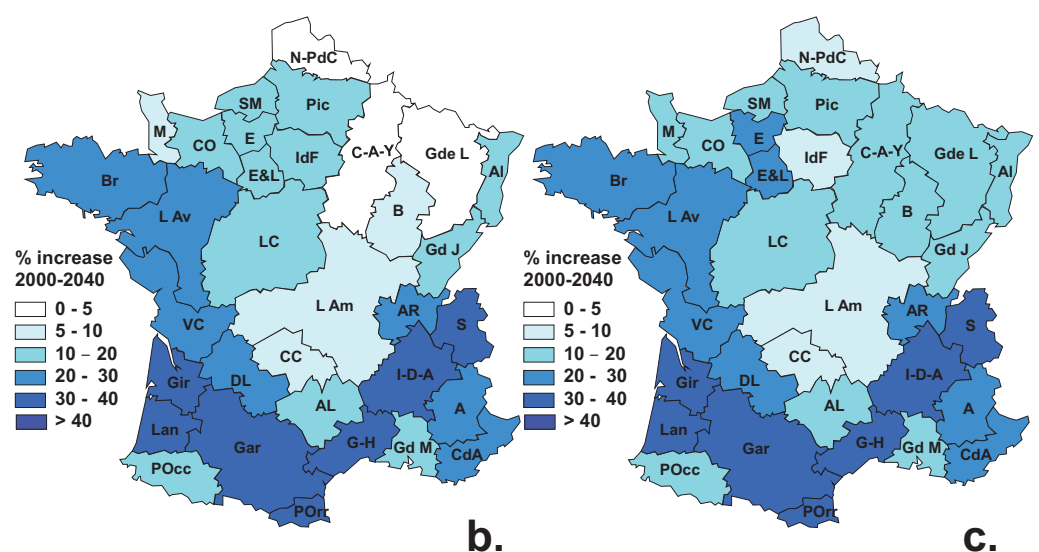

b.
C.

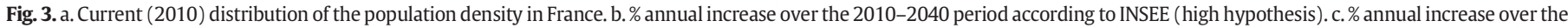

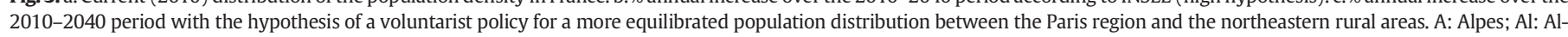

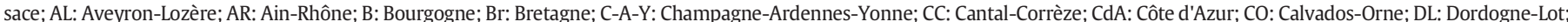

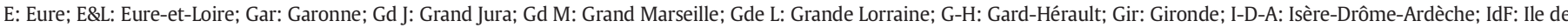

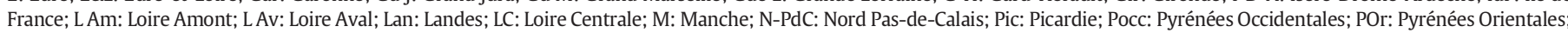
S: Savoie; VC: Vendée-Charentes. 
lower. For the Paris region, already by far the most populated region of the country (Fig. 3a), INSEE predicts an increase of 2.2 million inhabitants by 2040 . For the A/R/D scenario, we redistributed one million inhabitants from Ile-de-France to neighboring regions including the north and northeastern regions with weak demography (Fig. 3c).

Population development goes along with an increase in urban, builtup areas, which we assumed to be mostly subtracted from agricultural land. To calculate this land use change, we evaluated, in each region, the new built-up areas corresponding to the population increase, and to be subtracted from cropland, according to the following relationship, established from empirical data by Couturier et al. (2017), between built-up areas (Surb, ha) and population density (popdens, inhab/ $\mathrm{km}^{2}$ ) at the Nuts3 scale:

Surb $=1475 *$ popdens $^{(-0.6)}$

The food demand of the population is calculated for each scenario according to the corresponding average diet shown in Fig. 4 for the last 50 years for both scenarios.

\subsection{Cropping systems}

The Opening/Specialization scenario assumes the reinforcement of the currently observed specialization of agricultural regions as described by Le Noë et al. (2017, 2018b), with no major changes in the cropping systems. Because of strict environmental regulations, the rate of chemical fertilization is adjusted up to a cropland $\mathrm{N}$ soil balance of $50 \mathrm{~kg} \mathrm{~N} / \mathrm{ha} / \mathrm{yr}$. The corresponding yield is calculated assuming that the same Yield (Y, kg N/ha/yr) versus total $\mathrm{N}$ soil inputs (F, kg N/ha/yr) relationship holds true, averaged over the whole rotation cycle, for current and future cropping systems in each region. This $\mathrm{Y}$ vs $\mathrm{F}$ relationship can be expressed by a single parameter hyperbolic function (Lassaletta et al., 2014; Anglade et al., 2015):

$Y=Y \max F /(F+Y \max )$

The value of Ymax varies according to pedoclimatic context of each region (Fig. 5a), but the relationship (1) applies to crop rotation in use in organic farming as well as to conventional rotations (Fig. 5b), as shown by a compilation of enquiries available in different French agricultural regions.

For organic farming systems in the A/R/D scenario, a dominant crop rotation is assumed for each region (Table 1 ), characterized by a frequency of forage and grain legumes, and the corresponding yield of these legume crops (considered independent on the $\mathrm{N}$ fertilization rate). The total $\mathrm{N}$ soil input to the entire crop rotation can therefore be evaluated (taking into account regional livestock numbers; see below), and the yield of the non-legume crops can be calculated.

Similarly, the production of permanent grassland systems is calculated from the total of $\mathrm{N}$ input and the current Ymax value for grassland, considering the current rate of symbiotic atmospheric $\mathrm{N}$ fixation.

\subsection{Livestock distribution}

The reinforcement of regional specialization of the agricultural regions in France in the $\mathrm{O} / \mathrm{S}$ scenario would lead the regions of the central Paris basin, Nord-Pas-de-Calais, Alsace, Gironde, Landes and the regions of the extreme southeast to become completely devoid of livestock and grassland. Elsewhere, the livestock density would increase up to a density of $2 \mathrm{LU} /$ ha (livestock units per hectare agricultural area), the maximum allowed by European Nitrate Directive (91/676/CEE), with the same species composition as today. Feed is imported in case of insufficient local forage resources.

In the $\mathrm{A} / \mathrm{R} / \mathrm{D}$ scenario, all regions are considered as mixed crop and livestock farming areas, and livestock densities are adjusted to the availability of the forage resources of each region (no import of feed is allowed), with, however, an upper limit corresponding to a maximum cropland soil balance of $50 \mathrm{~kg} \mathrm{~N} / \mathrm{ha} / \mathrm{yr}$. The livestock species composition is kept identical to the current one for the regions currently characterized by mixed crop and livestock farming. For the other regions, we applied the specific composition of Grande Lorraine and Dordogne-Lot regions to the north and south of France, respectively. Grassland areas are adjusted to cover at least one-third of the livestock ration but cannot decrease below their current value.

\section{The GRAFS description of the scenarios}

The above storylines and hypotheses, summarized in Table 2, serve as input data for the GRAFS model based on a current reference situation corresponding to the average fluxes over the 2004-2014 period (Le Noë et al., 2017, 2018b). Small routines, developed as Macros appended to the GRAFS Excel files, allow adjusting synthetic fertilizer rates or livestock density in each region for the $\mathrm{O} / \mathrm{S}$ and $\mathrm{A} / \mathrm{R} / \mathrm{D}$ scenarios, respectively, following the respective constraints. The corresponding spreadsheets are provided as Supplementary material (SM2). Here we discuss the resulting description of the nutrient fluxes in both scenarios.

\subsection{Major $N$ fluxes at the national scale}

The results of the scenarios at the scale of the whole of France in terms of production and consumption of protein nitrogen are compared with the reference figures of the current situation (Table 3). The GRAFS

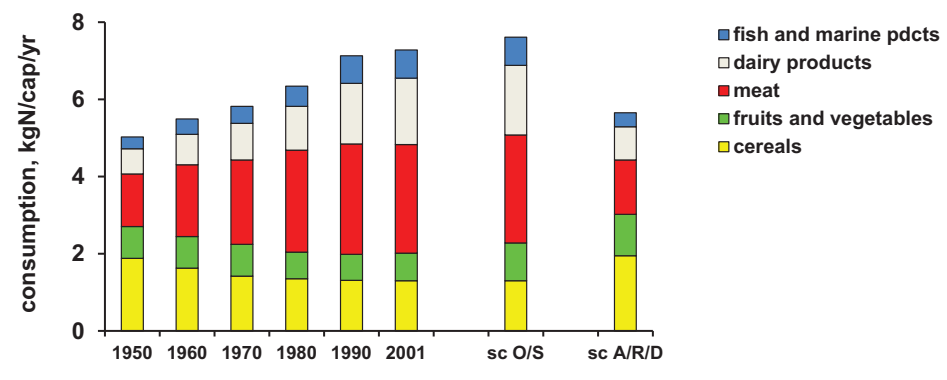

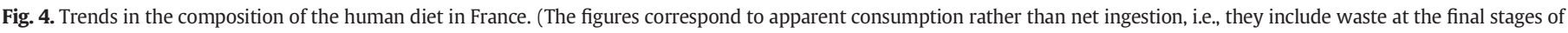

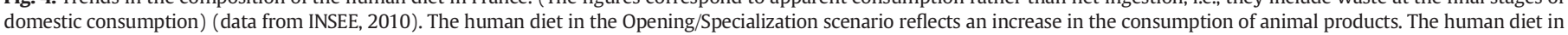
the Autonomous/Reconnected/Demitarian scenario replaces half of the animal proteins with vegetal proteins and avoids half of the waste at the consumer stage. 

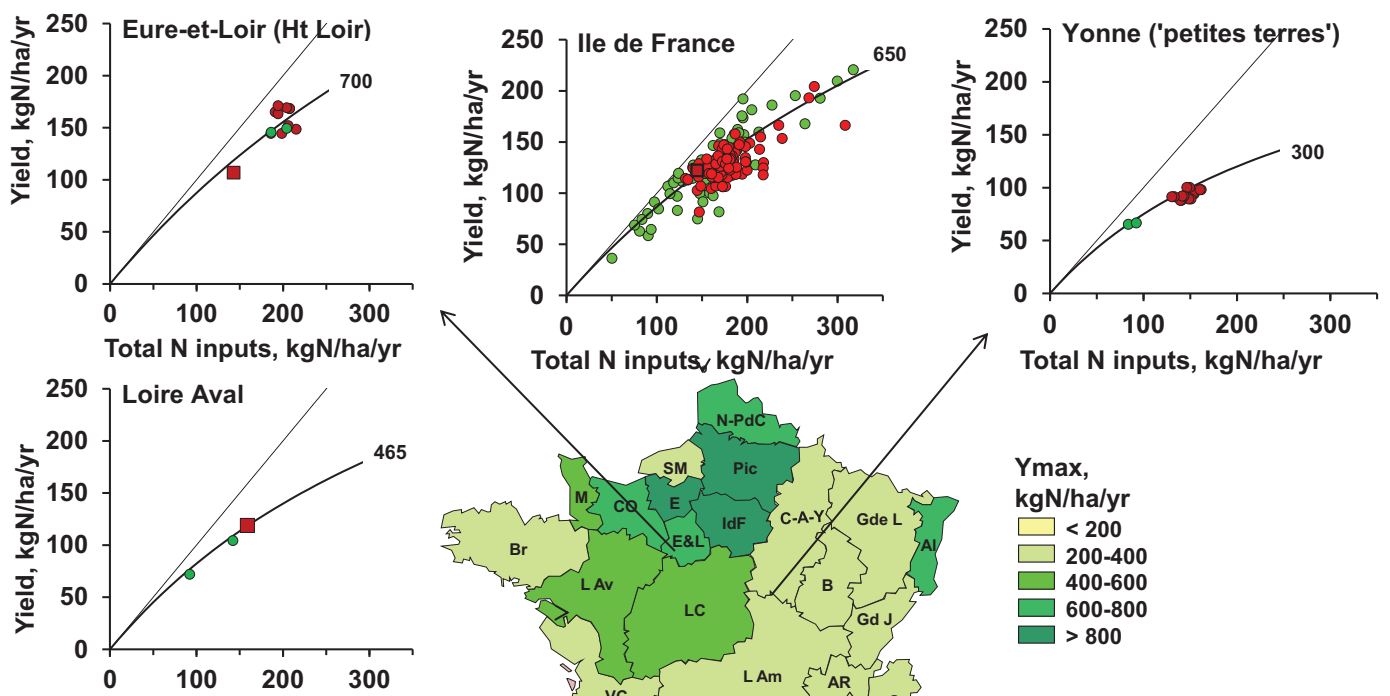

Total $\mathbf{N}$ inputs, kgN/ha/yr
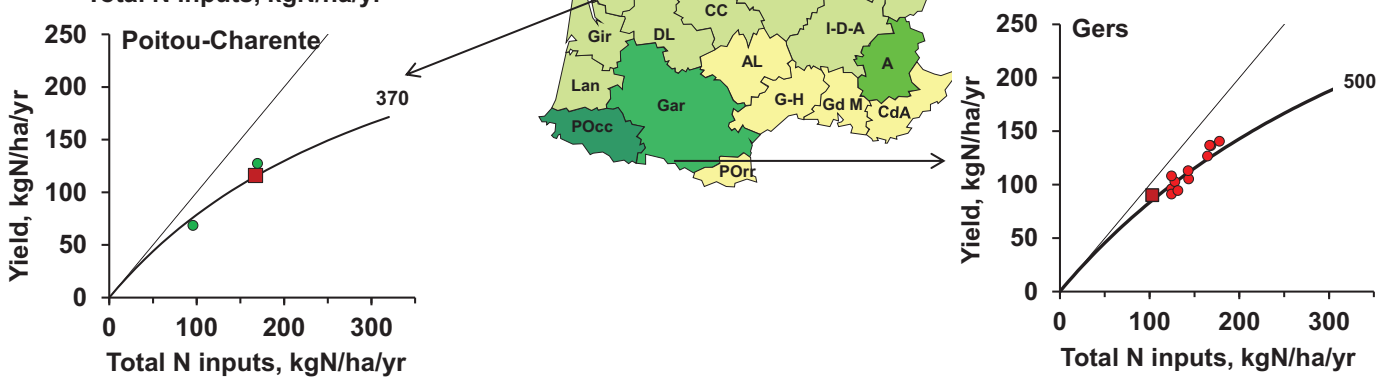

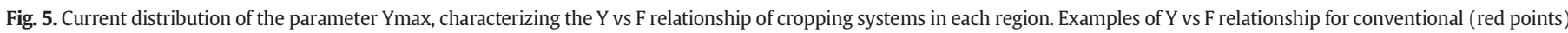

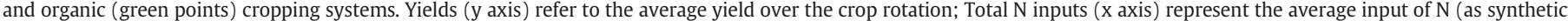

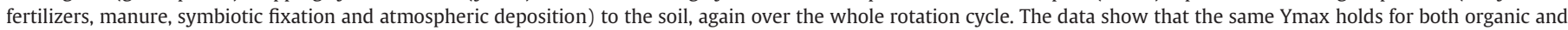

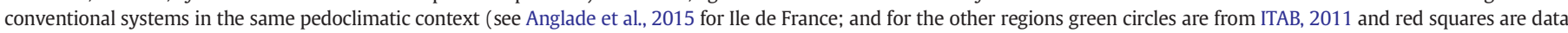

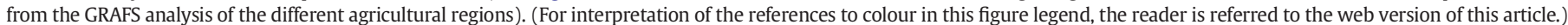

representation of the current and the two future scenarios are provided in Supplementary material SM3.

In the $\mathrm{O} / \mathrm{S}$ scenario, cropland production would increase by $15 \%$, potentially doubling cereal exports, in conformity with the explicit goal of this scenario. The number of livestock would also considerably increase, allowing a quite significant rise in animal product exports. The share of grassland in livestock nutrition would drop by one-third of its current value, and imported feed would become dominant in animal nutrition as is already the case in some French regions (Le Noë et al., 2017) and some European countries (Lassaletta et al., 2014). This requires four times more import of feed from abroad, changing the status of France from a net exporter of $\mathrm{N}$ agricultural products ( $100 \mathrm{kt} \mathrm{N} / \mathrm{yr})$ into a net importer ( 600 kt N/yr).

In the $\mathrm{A} / \mathrm{R} / \mathrm{D}$ scenario, in spite of the lack of use of synthetic $\mathrm{N}$ fertilizers and pesticides, cropland production would decrease by $<20 \%$. Owing to the reduction of livestock, this would not prevent a surplus of crop products with respect to the internal demand, available for export or other uses, such as energy production through methanation. In particular, about $220 \mathrm{kt} \mathrm{N} / \mathrm{yr}$ of cereals can be exported, accounting for $40 \%$ of the currently exported amount. Livestock nutrition would be entirely based on local grassland and cropland products (including $10 \%$ cereals), without any feed import. Nevertheless, this extensive animal production would fulfill the requirements of the 75 million demitarian inhabitants. Only a small quantity of high-quality and added-value products, such as AOC (registered designation of origin) cheese would be exported on the international market.

\subsection{Inter-regional exchanges}

Because of the concentration of population in a few large urban centers, several regions are not and will probably never be selfsufficient in terms of food. Based on the analysis of transport statistics, Le Noë et al. (2016) provided a matrix of the major fluxes of inter-regional exchanges of agricultural products in 2006 for France (Fig. 6). To draw a similar picture for the two scenarios (Fig. 6), we assumed that the probability of exchange of a particular product between two regions is inversely proportional to the distance between them and proportional to their respective supply potential and demand, thus considering an optimal spatial match between regional supply and demand. Besides international export of agricultural commodities, the long-distance international and inter-regional transport fluxes required to meet the local demand for food and feed amount $1400 \mathrm{kt} \mathrm{N} / \mathrm{yr}$ in the current situation; they increase to $1890 \mathrm{kt} \mathrm{N} / \mathrm{yr}$ in the $\mathrm{O} / \mathrm{S}$ scenario, and drops to only $94 \mathrm{kt} \mathrm{N} / \mathrm{yr}$ in the $\mathrm{A} / \mathrm{R} / \mathrm{D}$ scenario.

\subsection{Agronomical and environmental performances}

Several indicators of environmental performance can be calculated from the GRAFS representation of the scenarios. To provide only a few examples, we focus here first on the amount of external resources required by the agro-food system, with industrial fertilizers in the lead. Then we assess the risk of water resource contamination through $\mathrm{N}$ leaching. 
Table 1

Dominant crop rotation considered for organic farming in the different regions in the A/R/D scenario, and current yield of fodder and grain legumes involved. (Sources: Anglade et al., 2017; LeMaitre, pers. comm.; ITAB, 2011).

\begin{tabular}{|c|c|c|c|c|}
\hline Typical crop succession & $\begin{array}{l}\text { Frequency } \\
\text { cereals }\end{array}$ & Legumes & $\begin{array}{l}\text { Frequency } \\
\text { legumes }\end{array}$ & $\begin{array}{l}\text { Reference yield legume } \\
(\mathrm{kg} \mathrm{N} / \mathrm{ha} / \mathrm{yr})\end{array}$ \\
\hline $\begin{array}{l}\text { Paris basin (IdF, Picardy, Eure, Champ-Ard, ...) } \\
\text { Alf, Alf, W, Cer2, other, GrLeg, W, Cer3 }\end{array}$ & 0.5 & $\begin{array}{l}\text { Alf } \\
\text { GrLeg }\end{array}$ & $\begin{array}{l}0.25 \\
0.125\end{array}$ & $\begin{array}{l}250-300 \\
50-100\end{array}$ \\
\hline $\begin{array}{l}\text { Normandy (Calvados, Manche) } \\
\text { Clo, Clo, Mai, W, GLeg, W, Cer }\end{array}$ & 0.5 & $\begin{array}{l}\text { Clo } \\
\text { GrLeg }\end{array}$ & $\begin{array}{l}0.2 \\
0.2\end{array}$ & $\begin{array}{l}250 \\
95\end{array}$ \\
\hline $\begin{array}{l}\text { Nord-Pas de Calais } \\
\text { Luz, Pot, W, GLeg, W, Cer }\end{array}$ & 0.5 & $\begin{array}{l}\text { Luz } \\
\text { GLeg }\end{array}$ & $\begin{array}{l}0.17 \\
0.17\end{array}$ & $\begin{array}{l}280 \\
80\end{array}$ \\
\hline $\begin{array}{l}\text { Grande Lorraine } \\
\text { PT, PT, W, Cer/GrLeg, W, Cer }\end{array}$ & 0.58 & $\begin{array}{l}\text { PT } \\
\text { GrLeg }\end{array}$ & $\begin{array}{l}0.33 \\
0.08\end{array}$ & $\begin{array}{l}180 \\
73\end{array}$ \\
\hline $\begin{array}{l}\text { Alsace } \\
\text { Alf, Alf, W, Cer, Cer, Soy, Soy, Mai, Cer }\end{array}$ & 0.44 & $\begin{array}{l}\text { Alf } \\
\text { Soy }\end{array}$ & $\begin{array}{l}0.22 \\
0.22\end{array}$ & $\begin{array}{l}80 \\
290\end{array}$ \\
\hline $\begin{array}{l}\text { Britanny } \\
\text { Clo, Clo, Mai, W, Cer, GrLeg, W, Cer }\end{array}$ & 0.5 & $\begin{array}{l}\text { Clo } \\
\text { GrLeg }\end{array}$ & $\begin{array}{l}0.25 \\
0.125\end{array}$ & $\begin{array}{l}180 \\
100\end{array}$ \\
\hline $\begin{array}{l}\text { Vendée-Charente } \\
\text { Soy, W, Mai, GrLeg, W, Mai }\end{array}$ & 0.33 & Soy \& GrLeg & 0.33 & 80 \\
\hline $\begin{array}{l}\text { Loire Aval } \\
\text { Clo, Clo, Mai, GrLeg, W, other }\end{array}$ & 0.17 & $\begin{array}{l}\text { Clo } \\
\text { GrLeg }\end{array}$ & $\begin{array}{l}0.33 \\
0.17\end{array}$ & $\begin{array}{l}200 \\
75\end{array}$ \\
\hline $\begin{array}{l}\text { Loire Centrale } \\
\text { Alf, Alf, W, Cer, GrLeg, W, Cer }\end{array}$ & 0.57 & $\begin{array}{l}\text { Alf } \\
\text { GrLeg }\end{array}$ & $\begin{array}{l}0.29 \\
0.14\end{array}$ & $\begin{array}{l}210 \\
85\end{array}$ \\
\hline $\begin{array}{l}\text { Loire Amont } \\
\text { Alf, Alf, Alf, W, Cer, Sunfl, GrLeg, Mai, Sunfl, Cer }\end{array}$ & 0.3 & $\begin{array}{l}\text { Alf } \\
\text { GrLeg }\end{array}$ & $\begin{array}{l}0.3 \\
0.1\end{array}$ & $\begin{array}{l}260 \\
55\end{array}$ \\
\hline $\begin{array}{l}\text { Grand Jura } \\
\text { Alf, Alf, W, Cer, GrLeg, W, Cer, Mai }\end{array}$ & 0.44 & $\begin{array}{l}\text { Alf } \\
\text { GrLeg }\end{array}$ & $\begin{array}{l}0.33 \\
0.11\end{array}$ & $\begin{array}{l}180 \\
60\end{array}$ \\
\hline $\begin{array}{l}\text { Savoie } \\
\text { Al, Alf, Alf, W, Cer, Sunfl, GrLeg, W, Cer }\end{array}$ & 0.44 & $\begin{array}{l}\text { Alf } \\
\text { GrLeg }\end{array}$ & $\begin{array}{l}0.33 \\
0.11\end{array}$ & $\begin{array}{l}170 \\
60\end{array}$ \\
\hline $\begin{array}{l}\text { Ain-Rhone } \\
\text { Alf, Alf, Mai, GrLeg, W, Cer, Mai }\end{array}$ & 0.29 & $\begin{array}{l}\text { Alf } \\
\text { GrLeg }\end{array}$ & $\begin{array}{l}0.14 \\
0.29\end{array}$ & $\begin{array}{l}255 \\
72\end{array}$ \\
\hline $\begin{array}{l}\text { Alpes } \\
\text { Alf, Alf, Alf, W, Cer, Sunfl, W, Cerl }\end{array}$ & 0.44 & $\begin{array}{l}\text { Alf } \\
\text { GrLeg }\end{array}$ & $\begin{array}{l}0.33 \\
0.11\end{array}$ & $\begin{array}{l}190 \\
27\end{array}$ \\
\hline $\begin{array}{l}\text { Isère-Drome-Ardèche } \\
\text { Alf, Alf, W, Cer, Sunfl }\end{array}$ & 0.4 & Alf & 0.4 & 130 \\
\hline $\begin{array}{l}\text { Aveyron-Lozère } \\
\text { W, Sunfl, GrLeg }\end{array}$ & 0.33 & GrLeg & 0.33 & 43 \\
\hline $\begin{array}{l}\text { Garonne, PyrOcc } \\
\text { Soy, Sunfl, Cer }\end{array}$ & 0.33 & Soy & 0.33 & 55 \\
\hline $\begin{array}{l}\text { Gironde, Landes, Dor-Lot } \\
\text { Soy, Mai, Cer, GrLeg }\end{array}$ & 0.25 & Soy \& GrLeg & 0.5 & 63 \\
\hline $\begin{array}{l}\text { Cantal-Corrèze } \\
\text { Alf, Alf, Alf, W, Cer, Sunfl, GrLeg, Mai, Sunfl, Cer }\end{array}$ & 0.3 & $\begin{array}{l}\text { Alf } \\
\text { GrLeg }\end{array}$ & $\begin{array}{l}0.3 \\
0.1\end{array}$ & $\begin{array}{l}80 \\
40\end{array}$ \\
\hline $\begin{array}{l}\text { GdMarseille, Cote d'Azur,Gard-Héraut, PyrOr } \\
\text { W, Sunfl, GrLeg }\end{array}$ & 0.33 & GrLeg & 0.33 & $7-27$ \\
\hline
\end{tabular}

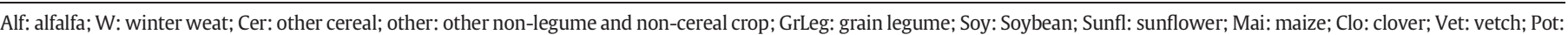
potatoes; PT: temporary grassland.

In the reference 2004-2014 period, the French agro-food system used $1890 \mathrm{kton} \mathrm{N} / \mathrm{yr}$ of nitrogen synthetic fertilizers applied over cropland and $67 \mathrm{kton} \mathrm{N} / \mathrm{yr}$ over permanent grassland. In the $\mathrm{O} / \mathrm{S}$ scenario, the figures would be quite similar (1870 and $72 \mathrm{kton} \mathrm{N} / \mathrm{yr}$, respectively, on cropland and grassland), while synthetic $\mathrm{N}$ fertilization would be inexistent by hypothesis in the A/R/D scenario. Regarding phosphorus 
Table 2

Main features of the O/S and A/R/D scenarios. (More details in Suppl. material 1).

\begin{tabular}{|c|c|}
\hline Opening/Specialization & Autonomy/reconnection/demitarian diet \\
\hline $\begin{array}{l}\text { Population } \\
\text { INSEE } 2040 \text { projection (elevated hyp) }\end{array}$ & $\begin{array}{l}\text { Idem with redistribution of } 1 \mathrm{M} \\
\text { additional inhabitants in Paris towards } \\
\text { the eastern }\end{array}$ \\
\hline $\begin{array}{l}\text { Human diet } \\
\text { Increased meat and milk consumption } \\
6.85 \mathrm{~kg} \mathrm{~N} / \mathrm{cap} / \mathrm{yr} \text { total proteins } \\
4.6 \mathrm{~kg} \mathrm{~N} / \mathrm{cap} / \mathrm{yr} \text { animal prot (excl fish) }\end{array}$ & $\begin{array}{l}\text { Demitarian diet } \\
5.56 \mathrm{~kg} \mathrm{~N} / \mathrm{cap} / \mathrm{yr} \text { total proteins } \\
1.93 \mathrm{~kg} \mathrm{~N} / \mathrm{cap} / \mathrm{yr} \text { animal prot (excl fish) }\end{array}$ \\
\hline $\begin{array}{l}\text { Agricultural area (AA) } \\
\text { Total AA reduced by urban sprawl } \\
\text { No perm. grassland in crop farming } \\
\text { areas } \\
\text { Same proportion to AA elsewhere }\end{array}$ & $\begin{array}{l}\text { Total AA identical to the current one. } \\
\text { Perm. grassland area: (1) never lower } \\
\text { that current level; (2) adjusted to } \\
\text { provide at least } 30 \% \text { of livestock feed. }\end{array}$ \\
\hline $\begin{array}{l}\text { Synthetic } \mathbf{N} \text { fertilization to cropland } \\
\text { Adjusted to maximize production up to } \\
\text { a maximum } \mathrm{N} \text { surplus of } 50 \mathrm{~kg} \\
\mathrm{~N} / \mathrm{ha} / \mathrm{yr} \text {. }\end{array}$ & Zero synthetic fertilization \\
\hline $\begin{array}{l}\text { Livestock } \\
\text { Crop farming regions: zero } \\
\text { Livestock farming regions: } 2.1 \mathrm{LU} / \mathrm{ha} \\
\text { UAA }\end{array}$ & $\begin{array}{l}\text { (1) No forage import } \\
\text { (2) } 30 \% \text { share of perm. grassland to } \\
\text { feed } \\
\text { (3) } \mathrm{N} \text { surplus }<40 \mathrm{~kg} \mathrm{~N} / \mathrm{ha} / \mathrm{yr}\end{array}$ \\
\hline
\end{tabular}

fertilizers, 145 kton P/yr were applied in the recent reference period over cropland and $90 \mathrm{kton} \mathrm{P} / \mathrm{yr}$ over permanent grassland. As shown by Le Noë et al. (2018a), these figures correspond to an unbalanced and often deficit $\mathrm{P}$ fertilization made possible by the existence of a considerable P legacy stored in agricultural soils during the 1960's-1990's. Ensuring an equilibrated soil $P$ balance in the $\mathrm{O} / \mathrm{S}$ scenario would require applying 170 kton $\mathrm{P} / \mathrm{yr}$ over cropland in the regions specialized in crop farming, while a large excess of soil $P$ input would be applied in livestock farming regions. In the A/R/D scenario, the exogenous $\mathrm{P}$ requirements for equilibrating the soil $\mathrm{P}$ balance would be $55 \mathrm{kton} \mathrm{P} / \mathrm{yr}$ on cropland and $12 \mathrm{kton} \mathrm{P} / \mathrm{yr}$ on grassland. About half of this P amount corresponds to the $\mathrm{P}$ contained in domestic wastewater; its possible recycling has not been considered in these two scenarios, beyond the current level of urban sludge application on cropland. The other half corresponds to the P content of exported vegetal production, mostly as cereal.

Cropland N soil surplus, an indicator of nitrate leaching to groundand surface water, is another major aspect of environmental performance (Fig. 7a). Taking into account the long-term average infiltration water depth in each region and assuming the surplus-nitrate leaching relationship discussed in Anglade et al. (2017), the nitrate concentration in groundwater recharge can be calculated (Fig. 7b) and compared with the WHO drinking water standard of $11 \mathrm{mg} \mathrm{N} / \mathrm{l}$ (i.e., $50 \mathrm{mg} \mathrm{NO}_{3} / \mathrm{l}$ ) and the recommended value of $5.6 \mathrm{mg} \mathrm{N} / \mathrm{l}$ by European standards (http:// www.eau-seine-normandie.fr/mediatheque/flipbook_sdage/index. html). Clearly, only in the A/R/D scenario would agriculture be compatible with good-quality drinking water production in most regions, even though the $\mathrm{O} / \mathrm{S}$ scenario has been established in compliance with current French and European regulations regarding reasoned fertilization and livestock densities.

\section{Discussion and conclusion}

This study first illustrates an original prospective approach for translating the storylines of two contrasted scenarios of the future French agro-food system into a quantitative description in terms of nutrient fluxes at the regional scale. For its application to prospective scenarios, we have added to the GRAFS methodology the capacity of translating a narrative description of a hypothetic future into a set of quantitative constraints, making it possible to establish a coherent and quantitative picture of the corresponding system at regional scales. In this way, GRAFS has gained the status of a dynamic predictive model.

One basic hypothesis making this translation possible is that of the regional invariance of the yield/fertilization relationship at the crop succession level. The empirical evidence presented in this paper fully justifies this hypothesis. It enables making predictions about agricultural production for hypothetical farming systems, given the total rate of $\mathrm{N}$ soil input, even in the absence of detailed agronomical references.

As mentioned above, the purpose of any prospective work is not to predict the future, but rather to produce extreme visions of what it could be, if some of the current trends were pushed to their logical limits. In that sense, the scenarios produced should not be considered as predictions or prescriptions. As stated by Découflé (1980), “a good scenario is by definition unacceptable. It is there to provoke the people to whom it is presented, to force them to question the hypotheses chosen. A scenario is made to be challenged and, once rejected, to feed another of its own remains." Nevertheless, it should not only nourish further

Table 3

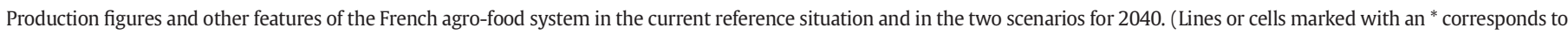
hypothesis of the scenarios. The others result from the GRAFS calculations).

\begin{tabular}{|c|c|c|c|c|}
\hline & & 2004-2014 reference & 2040 opening specialization & $\begin{array}{l}2040 \text { autonomy reconnection } \\
\text { demitarian diet }\end{array}$ \\
\hline Population* & Mhab & 62 & 75 & 75 \\
\hline Consumption vegetal proteins* & kt N/yr & 145 & 169 & 273 \\
\hline Consumption animal prot (excl fish)* & kt N/yr & 232 & 330 & 135 \\
\hline Agricultural area & Mha & 28 & 27 & 28 \\
\hline$\%$ permanent grassland & $\%$ & 34 & 29 & 36 \\
\hline Permanent grassland production & kt N/yr & 829 & 1093 & 633 \\
\hline Cropland production & kt N/yr & 2192 & 2508 & 1770 \\
\hline Cereal production & kt N/yr & 1218 & 1412 & 440 \\
\hline Forage production & kt N/yr & 831 & 837 & 1180 \\
\hline Net cereals import $(+) /$ export $(-)$ & kt N/yr & -540 & -1089 & -222 \\
\hline Livestock & M LU & 19 & 37 & 12 \\
\hline Meat and milk production & kt N/yr & 261 & 383 & 138 \\
\hline Meat and milk import $(+) /$ export $(-)$ & kt N/yr & -29 & -53 & -3 \\
\hline Livestock ingestion & kt N/yr & 1955 & 3731 & 1224 \\
\hline Perm grassland grazing & $\%$ & 42 & 29 & 45 \\
\hline Local cropland product ingestion & $\%$ & 35 & 26 & 55 \\
\hline Imported feed ingestion & $\%$ & 23 & 45 & $0^{*}$ \\
\hline Net feed import $(+) /$ export $(-)$ & kt N/yr & +438 & +1687 & $0^{*}$ \\
\hline
\end{tabular}



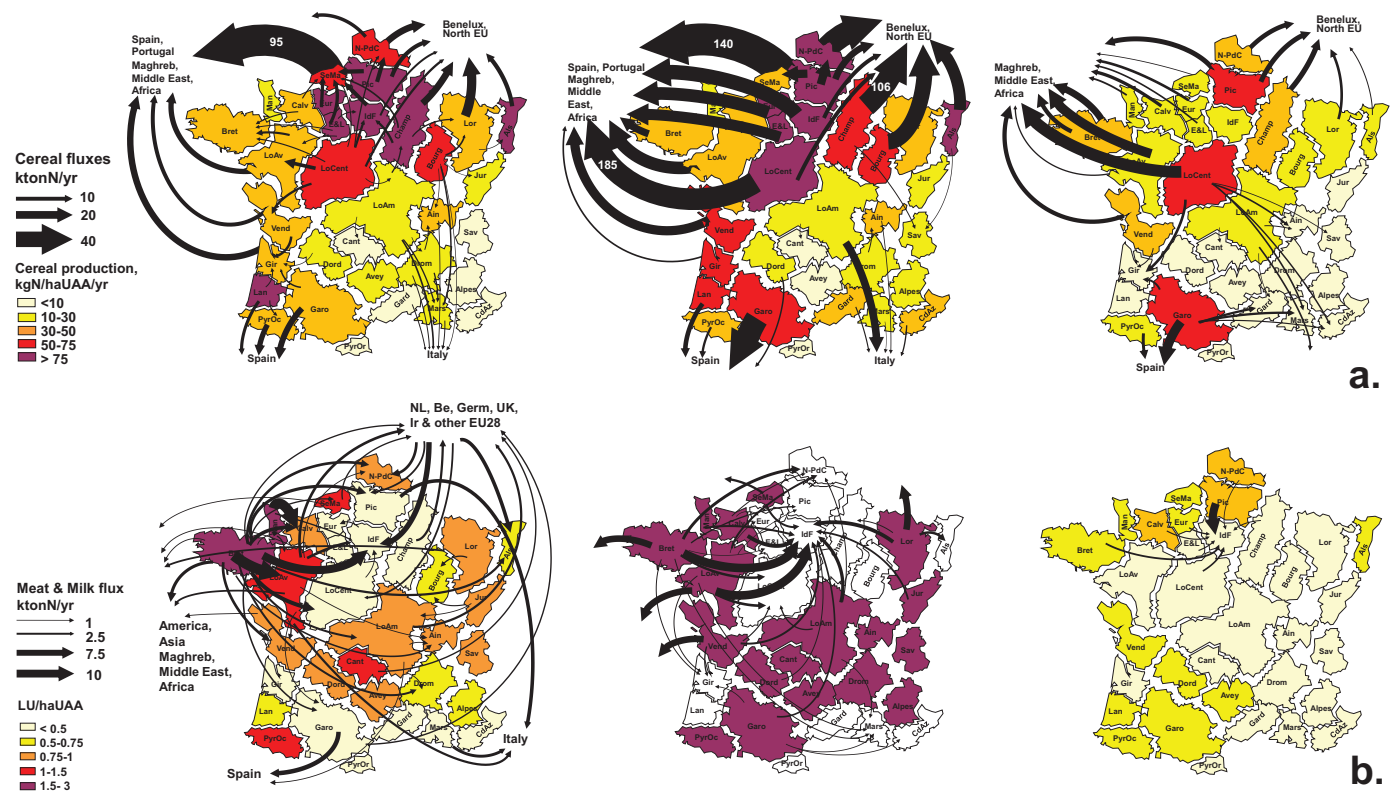

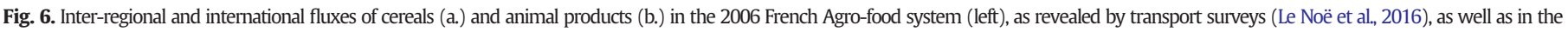

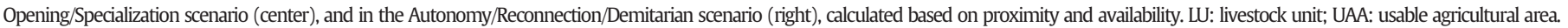

scenarios, but also make citizens and policy makers react because it reveals the range of open possibilities, which is shown to be much wider than often presented by mainstream thinking as the ineluctable productivist business-as-usual future (Fouilleux et al., 2017). Our study thus opens the way to the further elaboration of alternative scenarios for regional agro-food systems.

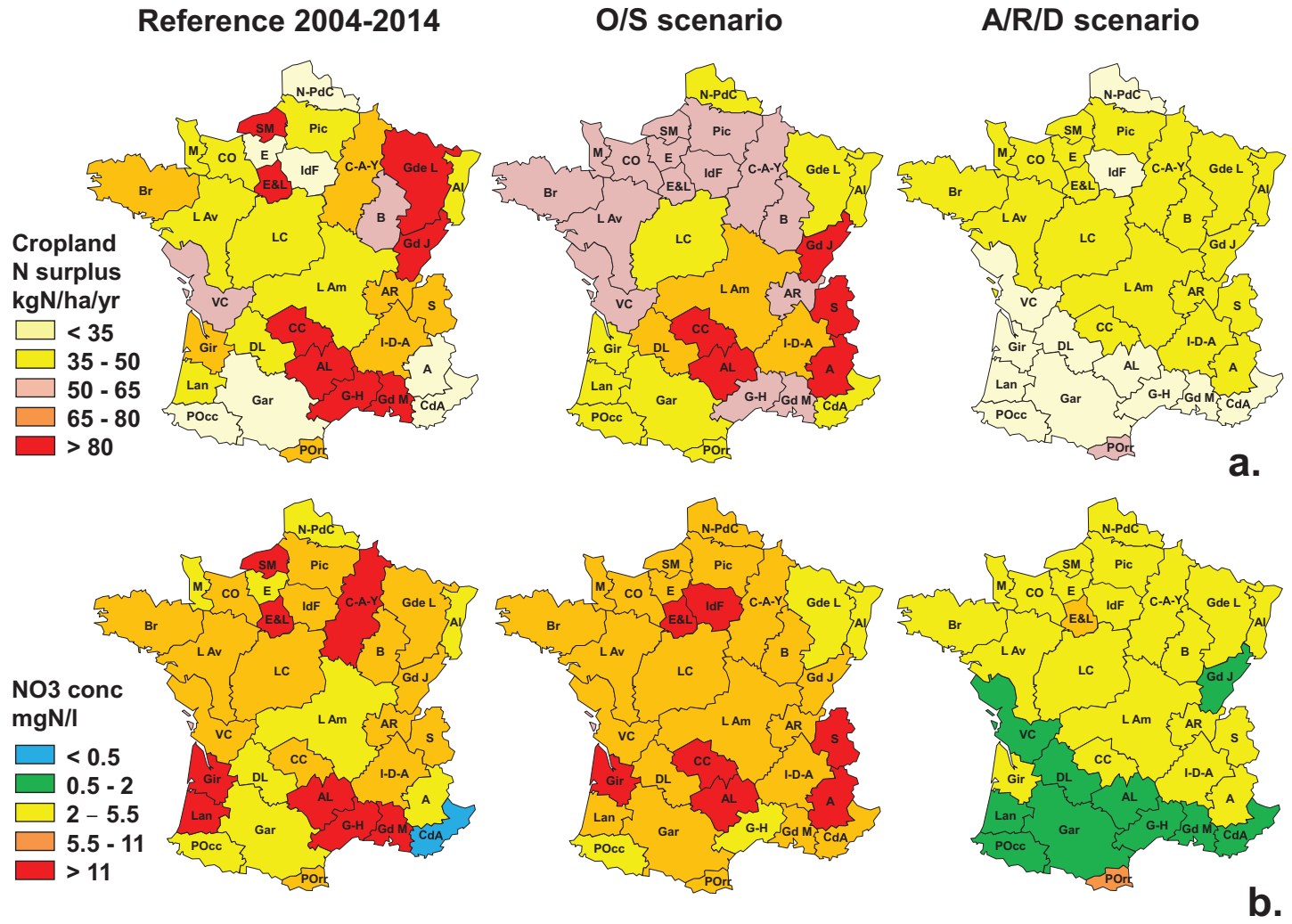

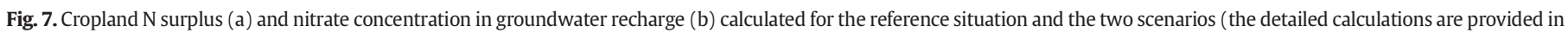
Suppl. material SM2). 
First, we demonstrated the close interconnection between agricultural practices, production structure and human diet, three key aspects of the agro-food system that have to be considered together in any scenario (Schader et al., 2015). Indeed, current fertilization practices in France generally meet the regulatory nutrient balance with respect to yield objectives in each region (Anglade et al., 2017). No further improvement of the performances of the agro-food system can therefore be expected without deep structural changes in the system itself, or in the final demand induced by the dietary habits of the population.

A major conclusion of this study is the feasibility, in terms of nutrient fluxes, of an agro-food system based on (i) autonomy with respect to industrial fertilizers and imported feed, (ii) reconnection of crop and livestock farming and (iii) a diet with reduced animal protein, as in the A/R/ D scenario. Such a scenario applied to France is in line with some of the global scenarios privileging food sovereignty and organic farming techniques (Kastner et al., 2012, 2014; Pradhan et al., 2014; Billen et al., 2015; Erb et al., 2016; Lassaletta et al., 2016; Muller et al., 2017). Indeed, none of those scenarios predicts full self-sufficiency of all world regions at the 2050 horizon, making a certain amount of international trade of agricultural goods and a certain degree of openness of local economies unavoidable. In that respect it is notable that our extreme A/R/D scenario for France would allow net cereal exports at more than twothirds of the current level, while no imports of feed would be necessary. On the contrary, the $\mathrm{O} / \mathrm{S}$ scenario, because of its reliance on imported feed, would bring France from a net exporter to a net importer of agricultural goods.

Finally, even if current regulations regarding reasoned fertilization and livestock density have been taken into account in the construction of the $\mathrm{O} / \mathrm{S}$ scenario, this is not sufficient to ensure good water quality in most regions, thus suggesting that deep structural changes in the agro-food system, as in the A/R/D scenario, are necessary to reconcile agriculture and water quality. Reconciling sustainable agriculture with water quality has been proved possible at several scales (from small catchments in Garnier et al., 2016, to the regional domain of the Atlantic façade, as in Desmit et al., 2018). The regional level, as investigated here, has already been argued to be the most pertinent scale for changing the structure of the current food system (Clancy and Ruhf, 2010).

On the whole, these results show that the future of the French agrofood system will depend on the tradeoffs between two diametrically opposed trends, which corresponds to two markedly different political visions of society: (i) a centrifugal trend promoting opening of agricultural production to international markets with specialization in activities presenting comparative advantages and economies of scale, and (ii) a centripetal trend developing innovative forms of relocation of agricultural production and food consumption, creating new links between actors at the regional scale for a better closure of nutrient cycles.

Supplementary data to this article can be found online at https://doi. org/10.1016/j.scitotenv.2018.05.043.

\section{Acknowledgements}

This work has been carried out within the scope of several research projects including PIREN-Seine (CNRS/AESN), RESET (Seine-Aval) and Emosem (EU Seas-era). Thanks are also due to the Fédération Ile-deFrance de Recherche pour l'Environnement (FIRE) for providing an interdisciplinary framework that was beneficial for this work. Julia Le Noë's PhD is granted by the Ecole Doctorale Géosciences, Ressources Naturelles et Environnement (GRNE, ED).

\section{References}

Anglade, J., Billen, G., Makridis, T., Garnier, J., Puech, T., et Tittel, C., 2015. Nitrogen soil surface balance of organic vs conventional cash crop farming in the Seine watershed. Agric. Syst. 139, 82-92.

Anglade, J., Billen, G., Garnier, J., 2017. Reconquérir la qualité de l'eau en régions de grande culture: agriculture biologique et reconnexion avec l'élevage. Fourrages 231, 257-268.
Billen, G., Garnier, J., Lassaletta, L., 2013. The nitrogen cascade from agricultural soils to the sea: modelling nitrogen transfers at regional watersheds and global scales. Philos. Trans. R. Soc. B 368, 20130123.

Billen, G., Lasseletta, L., Garnier, J., 2014. A biogeochemical view of the global agro-food system: nitrogen flows associated with protein production, consumption and trade. Glob. Food Sec. 3:209-219. https://doi.org/10.1016/j.gfs.2014.08.003i.

Billen, G., Lassaletta, L., Garnier, J., 2015. A vast range of opportunities for feeding the world in 2050: trade-off between diet, N contamination and international trade. Environ. Res. Lett. 10, 025001. https://doi.org/10.1088/1748-9326/10/2/025001.

Bureau, J.-C., Thoyer, S., 2014. La politique agricole commune. La Découverte, Paris.

Clancy, K., Ruhf, K., 2010. Is local enough? Some arguments for regional food systems. Choices 25 (1). http://www.choicesmagazine.org/UserFiles/file/article_114.pdf.

Couturier, C., Charru, M., Doublet, S., Pointereau, P., 2017. Le scénario Afterres 2050. Solagro www.afterres2050.solagro.org.

Crowder, D.W., Northfield, T.D., Strand, M.R., Snyder, W.E., 2010. Organic agriculture promotes evenness and natural pest control. Nature 466, 109-113 09183.

de Vries, W., Kros, J., Kroeze, C., Seitzinger, S.P., 2013. Assessing planetary and regional nitrogen boundaries related to food security and adverse environmental impacts. Curr. Opin. Environ. Sustain. 5, 392-402.

Découflé, C., 1980. La prospective. PUF, Paris, France.

Desmit, X., Thieu, V., Dulière, V., Ménesguen, A., Campuzano, F., Lassaletta, L., Sobrinho J.L., Silvestre, M., Garnier, J., Neves, R., Billen, G., Lacroix, G., 2018. Reducing marine eutrophication may require a paradigmatic change. Sci. Total Environ. 635:1444-1466. https://doi.org/10.1016/j.scitotenv.2018.04.1.

Direction Générale de la Santé, 2012. Abandons de captages utilisés pour la production d'eau destinée à la consommation humaine. Bilan Février 2012, secrétariat d'Etat chargé de la santé.

Duszinski, J., 2013. Filière céréales en Vallée de Seine: quelle perspective de développement? Mémoire-projet MBA Maritime, transport et logistique. Ecole de Management de Normandie.

Erb, K.-H., Lauk, C., Kastner, T., Mayer, A., Theurl, M.C., Haberl, H., 2016. Exploring the biophysical option space for feeding the world without deforestation. Nat. Commun. 7, 11382.

Fouilleux, E., Bricas, N., Alpha, A., 2017. 'Feeding 9 billion people’: global food security debates and the productionist trap. J. Eur. Publ. Policy 24:1658-1677. https://doi.org/ 10.1080/13501763.2017.1334084.

Garnier, J., Anglade, J., Benoit, M., Billen, G., Puech, T., Ramarson, A., Passy, P., Silvestre, M., Lassaletta, L., Trommenschlager, J.-M., Schott, C., Tallec, G., 2016. Reconnecting crop and cattle farming to reduce nitrogen losses in river water of an intensive agricultural catchment (Seine basin, France). Environ. Sci. Pol. 63, 76-90.

Haropa, 2014. Projet stratégique 2015-2020. Paris.

ITAB, 2011. Rotations en grandes cultures biologiques sans élevge. Réseau expérimental RotAB www.itab.asso.fr/downloads/rotab/rotab-broch-fertilite.pdf.

Kastner, T., Rivas, M.J.I., Koch, W., Nonhebel, S., 2012. Global changes in diets and the consequences for land requirements for food. Proc. Natl. Acad. Sci. U. S. A. 109, 6868-6872.

Kastner, T., Erb, K.-H., Haberl, H., 2014. Rapid growth in agricultural trade: effects on global area efficiency and the role of management. Environ. Res. Lett. 9, 034015.

Lassaletta, L., Billen, G., Grizzetti, B., Anglade, J., Garnier, J., 2014. 50 year trends in nitrogen use efficiency of world cropping systems: the relationship between yield and nitrogen input to cropland. Environ. Res. Lett. 9. https://doi.org/10.1088/1748-9326/9/10/105011.

Lassaletta, L., Billen, G., Garnier, J., Bouwman, L., Velazquez, E., Mueller, N.D., Gerber, J.S., 2016. Nitrogen use in the global food system: past trends and future trajectories of agronomic performance, pollution, trade, and dietary demand. Environ. Res. Lett. 11 (2016), 095007. https://doi.org/10.1088/1748-9326/11/9/095007.

Le Monde, 2017. http://www.lemonde.fr/planete/article/2017/08/11/le-scandalealimentaire-scenario-a-repetition-de-l-agroalimentation-mondialisee_5171473_ 3244.html.

Le Nechet, R., Michaud, M., Legrain, P., Hirschler, J., Pas, N., Chauvin, S., Lafont, M., 2006. 2020: Que mangerons-nous? Enjeux pour les productions agricoles Normandes. Chambre d'Agriculture de Normandie.

Le Noë, J., Billen, G., Lassaletta, L., Silvestre, M., Garnier, J., 2016. La place du transport de denrées agricoles dans le cycle biogéochimique de l'azote en France: un aspect de la spécialisation des territoires. Cahiers Agricultures 25, 15004. https://doi.org/ 10.1051/cagri/2016002.

Le Noë, J., Billen, G., Garnier, J., 2017. How the structure of agro-food systems shapes nitrogen, phosphorus, and carbon fluxes: the generalized representation of agro-food system applied at the regional scale in France. Sci. Total Environ. 586, 42-55.

Le Noë, J., Billen, G., Garnier, J., 2018a. Phosphorus management in cropping systems of the Paris Basin: from farm to regional scale. J. Environ. Manag. 205, 18-28.

Le Noë, J., Billen, G., Esculier, F., Garnier, J., 2018b. Long term socio-ecological trajectories of agro-food systems revealed by $\mathrm{N}$ and $\mathrm{P}$ flows: the case of French regions from 1852 to 2014. Agric. Ecosyst. Environ. (in press).

Lestel, D., 2017. Apologie du Carnivore. Fayard, Paris.

Maillot, M., Issa, C., Vieux, F., Lairon, D., Darmon, N., 2011. The shortest way to reach nutritional goals is to adopt Mediterranean food choices: evidence from computergenerated personalized diets. Am. J. Clin. Nutr. 94, 1127-1137.

Mew, M.C., 2016. Phosphate rock costs, prices and resources interaction. Sci. Total Environ. 542, 1008-1012.

Ministère de l'Agriculture, de l'Agro-alimentaire et de la Forêt, 2012. Panorama des industries agroalimentaires. Editions 2012. http://www.agroalimentaire-lr.com/sites/aria. choosit.eu.

Muller, A., Schader, C., El-Hage Scialabba, N., Brüggemann, J., Isensee, A., Erb, K.-H., Smith, P., Klocke, P., Leiber, F., Stolze, M., Niggli, U., 2017. Strategies for feeding the world more sustainably with organic agriculture. Nat. Commun. 8:1290. https://doi.org/ 10.1038/s41467-017-01410-w. 
Porcher, J., 2011. Vivre avec les animaux. La Découverte, Paris.

Pradhan, P., Lüdeke, M.K.B., Reusser, D.E., Kropp, J.P., 2014. Food self-sufficiency acros scales: how local can we go? Environ. Sci. Technol. 48:9463-9470. https://doi.org/ 10.1021/es5005939.

Rockström, J., Steffen, W., Noone, K., Persson, A., Chapin, S., Lambin, E.F., Lenton, T.M. Scheffer, M., Folke, C., Schellnhuber, H.J., Nykvist, B., de Wit, C.A., Hughes, T., van der Leeuw, S., Rodhe, H., Sörlin, S., Snyder, P.K., Costanza, R., Svedin, U., Falkenmark, M., Karlberg, L., Corell, R.W., Fabry, V.J., Hansen, J., Walker, B., Liverman, D. Richardson, K., Crutzen, P., Foley, J.A., 2009. A safe operating space for humanity. Nature 461, 472-475.

Sarkozy, N., 2009. Déclaration sur la politique maritime de la France, Le Havre le 16 juille 2009. http://discours.vie-publique.fr/notices/097002118.html.

Schader, C., Muller, A., El-Hage Sdalabba, N., Hecht, J., Isensee, A., Erb, K.-H., Smith, P., Makkar, H.P.S., Klocke, P., Leiber, F., Schwegler, P., Stolze, M., Niggli, U., 2015. Impacts of feeding less food-competing feedstuffs to livestock on global food system sustainability. J. R. Soc. Interface 12, 20150891.
Schmitz, C., Biewald, A., Lotze-Campen, H., Popp, A., Dietrich, J.P., Bodirsky, B., Krause, M., Weindl, I., 2012. Trading more food: implications for land use, greenhouse gas emissions, and the food system. Glob. Environ. Chang. 22:189-209. https://doi.org/ 10.1016/j.gloenvcha.2011.09.013.

Singer, P., 1975. Animal Liberation. A New Ethics for Our Treatment of Animals. Harper Collins, p. 311.

Smith, P., 2013. Delivering food security without increasing pressure on land. Glob. Food Sec. $2,18-23$.

Timmer, C.P., 2008. Causes of high food prices. ADB economics working paper series 128. Available at:. https://www.econstor.eu/handle/10419/109323.

United Nations, 2015. Transforming Our World: The 2030 Agenda for Sustainable Development. United Nations. 